Proceeding of the Public Health and Well-being Conference, Vol. 2, 2021, pp. 1-21

Copyright (C) 2021 iConferences

ISSN 2659-2096

DOI: https://doi.org/10.32789/publichealth.2021.1001

\title{
The Moderating Effect of Beliefs on HPV Awareness and HPV Vaccination Acceptance among Female Patients in Islamabad City
}

\author{
Afifa Muhammad Afzal ${ }^{1}$ \\ ${ }^{1}$ Riphah International University, Pakistan, getafifa@gmail.com
}




\title{
THE MODERATING EFFECT OF BELIEFS ON HPV AWARENESS AND HPV VACCINATION ACCEPTANCE AMONG FEMALE PATIENTS IN ISLAMABAD CITY
}

\begin{abstract}
This research aimed to study the effect of awareness on the acceptability of human papillomavirus vaccination with belief acting as a moderator between the two variables. Quantitative research was conducted in a hospital with a specific focus on gynecological operations and family planning. The method of data collection comprised of a questionnaire, which was filled out by 50 women from various religious and cultural backgrounds. SPSS was used to conduct statistical analysis. The univariate, bivariate, and multivariate analyses indicated that the results were not conclusive with the hypothesis. The participants had no pre-existing information regarding vaccinations and the knowledge of the diseases being studied as opposed to the hypothesis. This research brings focus towards a deeply neglected area of reproductive healthcare in Pakistan. This includes a lack of awareness amongst the population regarding HPV. Lack of concrete and accurate knowledge directly affects the amount of awareness present in Pakistan regarding HPV, which is close to zero, as indicated by this study. This absence of awareness means that we, as healthcare practitioners, cannot research the current topic and expect it to produce any conclusive results.
\end{abstract}

Keywords: Human Papillomavirus, Vaccination, HPV, Awareness, Acceptability, Beliefs

\section{Introduction}

According to the World Health Organization (WHO), Human Papillomaviruses (HPV) is one of the most common forms of cancer (World Health Organization, 2017). The infection alone doesn't cause any infection unless continuously exposed to it. HPV is the primary cause of cervical cancer which usually doesn't occur until years have passed. The infection affects the epithelial layer of the host and is viral. Entry into the epithelial layer triggers the virus to further expand towards the final stage of the infection (Khan et al., 2007).

Currently, there are three vaccinations available for cancer treatment around the world. To prevent high-risk HPV infection 16 and 18, vaccination named Cervarix are available in the market. These genotypes are closely associated with $70 \%$ of the cervical cancer cases in low and high-grade squamous inter-epithelial lesions (Clifford, Smith, Aguado \& Franceschi). The quadrivalent HPV vaccine includes the Gardasil and Sanofi MSD, which, apart from the genes mentioned above, also target LR HPV 6 and 11. The latter is associated with 90\% of inner genital warts in men and women (Braatan and Luafer, 2008). Both the bivalent and the tetravalent vaccines have shown their 
effectiveness in the trials conducted in recent years (Harper \& DeMars, 2017). Finally, apart from covering the four genotypes of the quadrivalent vaccine, the 9-valent or the Gardasil9 targets five additional HR HPV genotypes (31/33/45/52/58) (Capra et al., 2017). The vaccination needs to be administered to those who are not sexually active yet in three rounds. Therefore, it is preferred that the vaccination be given at a young age (Loke, Kwon, Wong \& Wong, 2017)

Developed countries like Australia, Hungary, and the United Kingdom have included HPV vaccination as part of the national vaccination program (Yu et al., 2016). With the spread of the HPV epidemic in 2014, about 84 countries incorporated it into their national vaccination and immunization programs. The Human Papillomavirus report of 2019 shows lack of HPV vaccinations and immunization programs, leading to a major epidemic and causing many fatal deaths (Bruni et al., 2019).

Being a developing country, Pakistan's public health faces a major threat in terms of this virus. Up till now, there is no set HPV screening program set up in the country. Social restrictions have been named the greatest hurdle to HPV's statistical analysis (Khan et al., 2007). Even during the twentieth century, Pakistan's population considers it taboo to discuss sexually transmitted diseases (STDs) and gender-specific cancers. The data collected from the crude incidence report places the infection at the rate of 5.9. In 2013, Pakistan saw 5233 cases of cervical cancer, out of which 2876 resulted in death (Center I.H.I, 2016). Screening studies have reported HR cervical cancer in the Punjab region (Gul, Murad, and Javed, 2015). Lack of public health initiatives has resulted in lack of HPV awareness and knowledge. While the internet and blogs have helped build positive perception and awareness, the lack of provincial and nationwide campaigns has kept the standard of awareness as low as possible (Khan, Buksh, Rehman, and Saleem, 2016).

While there might be some research in terms of raw data, little to no research has been done to study the effect of beliefs, acceptability, and knowledge on HPV vaccination after receiving awareness. This study aims to assess knowledge and attitude towards HPV vaccination among adult women to disseminate the culture of vaccination by increasing parental awareness and attitude.

\section{Literature Review}

\section{Human Papillomavirus Virus Vaccination}

The Human Papillomavirus Virus (HPV) is the second leading cause of cancer in women worldwide (Schoell, Janecik \&Mirhashemi, 1999). Not all HPV infections turn into cancer. Most appear to resolve in two to three years, while others advance to the next level (Langsfield \& Laimins, 2016). At least fifteen countries have shown a decline in HPV infection due to the growing awareness and acceptance of HPV vaccination (Drolet et al., 2015). These countries have a high-quality screening methodology which includes recommendations, over-lapping ages screening top-notch vaccination registry records (Brothoren, 2019). Furthermore, countries where men have gone through pre and post HPV vaccination evaluation and women-only HPV vaccination programs have created herd protection (Chow et al., 2017). This herd protected community may occur where only $30 \%$ of the population is 
vaccinated, further establishing up to $80 \%$ protection if both males and females vaccinate for 70 years (Brisson et al., 2016).

However, in countries like Pakistan, where discussing sexually transmitted diseases is taboo, HPV vaccinations are not popular. This also includes HPV screening because risk factors and mode of transmission have not been evaluated amongst Pakistani women (Khan et al., 2007). The present study was carried out to study the moderating effect of religious beliefs on awareness and intention of HPV vaccination, mediated by the acceptability of immunotherapy in Pakistani society.

\section{Awareness of the HPV Vaccine and Acceptability of the Vaccine}

Lechuga, Vera-Cala, and Martinez (2014) researched Latina women's heightened risk of acquiring HPV infection. It was a population-based survey conducted via phone calls. The results from the research suggested that lack of awareness about the HPV vaccination negatively affects the intention to provide immunotherapy to their daughters. There was a fear about side effects, peer pressure, and the perceived idea of their daughters becoming sexually active. Similarly, Kim (2015) conducted a study on Korean youth studying in grade five. These students were first evaluated on their general knowledge about HPV, resulting in significantly different responses between the genders. However, after education was provided, gender disparities significantly improved in terms of responses. Thereby, Kim concluded that increase HPV awareness could positively influence the intention to obtain the HPV vaccine. In another paper by Santhanes et al. (2018), research was conducted by analyzing nineteen studies qualitatively via meta-analysis and systemic review. The papers were taken from studies conducted in Southeast Asia and Western Pacific region. The results showed that women who thought they were at risk of getting the infection had high intentions of getting vaccinated. However, those who had little to no knowledge didn't think it was necessary to get themselves vaccinated. In another cross sectional study, college women from Thailand were examined for HPV vaccination knowledge (Ratanasiripong, Sri-Umporn, Kathalae, Hanklang, \& Ratanasiripong, 2018). This research was conducted by getting questionnaires filled out. The study results showed that most women perceived themselves at low risk of getting HPV infection; thereby, they didn't feel the need to get themselves vaccinated. It was concluded that lack of knowledge has a negative effect on an individual's acceptability towards the vaccine.

H1: Lack of awareness can negatively affect acceptance to acquire HPV vaccination.

\section{Beliefs about Awareness and Acceptability of HPV Vaccination}

There is a general idea that an individual's beliefs can affect one's decision to vaccinate themselves. In an article posted by Grand Valley state university (2014), research was carried out in which 1000 students participated. The result of the study showed that religious beliefs and social norms influenced once acceptability of HPV vaccination. Shelton, Snavely, De Jesus, Othus, \& Allen (2011) conducted a web-based survey with parents of daughters between the ages of 9 and 17. The results from the study showed that Catholic parents were more likely to have their daughters vaccinated than nonaffiliated parents. Protestants who were constant church visitors showed a negative attitude towards getting their daughters vaccinated. The latter ones didn't want their children to get vaccinated at all. In 
another study, women in the SEAR and WPR showed doubts about HPV vaccination as they didn't have enough knowledge of its efficacy (Santhanes et al., 2018).

However, research on beliefs is inconsistent. One such study conducted by Grandahl et al. (2018) showed that parents who considered religion an important aspect of their lives wanted to get their daughters vaccinated. On the contrary, parents who did not associate themselves strongly with any religion were against HPV vaccination. Krawczyk et al. (2015) reported similar results. The research was done in Quebec, and 774 parents were sent questionnaires by mail. These parents had daughters between the ages of $9-10$ years old. Out of the 774 parents, about $80 \%$ reported that they already got their daughters vaccinated for HPV. The rest were against this idea. Of these $80 \%$ results, Christian parents were more likely to get their daughter vaccinated than non-Christian parents.

$\mathrm{H} 2$ : Beliefs positively moderating the relationship between HPV Vaccination awareness and acceptability

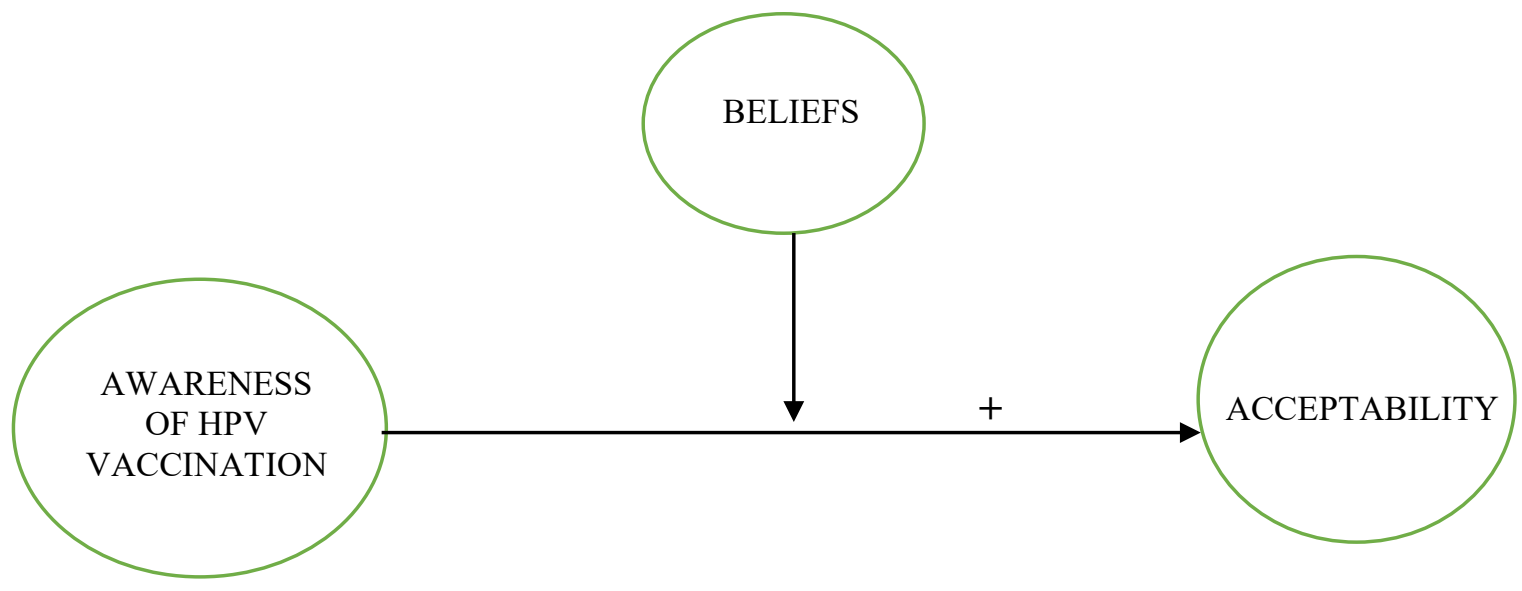

Figure 1 Research Model

\section{Methodology}

\section{Participants of the Study}

Females were the primary participants chosen for the study. These were patients of a hospital who were regular visitors of the Family Planning department. Since all of these participants visited the department, it is perceived that their lack of knowledge of HPV vaccination would help improve Pakistan's family planning programs set up in hospitals and clinics.

The patients were aged between 20 to 40 years. Out of 50 participants, 43 were Muslims, 5 were Christians, and 1 was Hindu. 1 participant chose not to share that information. $20 \%$ of the participants had finished middle school education. 24\% completed high school education. 36\% 
completed intermediate education. 12\% completed bachelor's education. $4 \%$ completed master's education. Only 2 participants reported no form of education.

As this research was conducted by voluntary participation, participants were guaranteed confidentiality and anonymity. All participants were females.

\section{Scales of Measure}

All variables were measured using a 5 point Likert scale. For the first two sections (A and B), "Yes was equal to 1, whereas "No" was equal to 5 . For the next two sections (C and D), "Strongly Agree" was equal to 1, and "Strongly Disagree" was equal to 5.

All participants were Urdu speakers with little to no knowledge of the English language; therefore, the questionnaires were translated by a team of verified translators of the National University of Modern Languages. To check for the reliability of translation, the back-translation method was done. (See Appendix 2).

\section{General Awareness of Vaccines}

The questions for the variable were taken from Matranga et al. (2019). It had 8 items in total. Sample items included "Do you know by who and when can you get vaccinated?". The chronebach's alpha reliability was found to be 0.768 .

\section{Specific Awareness of HPV Vaccines}

The questions for the variable were taken from Matranga et al. (2019). It has 8 items in total. Sample items included, "Do you think that HPV is dangerous?". The chronebach's alpha reliability was found to be 0.558 .

\section{Role of belief on HPV and HPV Vaccination}

The questions for the variable were taken from Grandahl et al. (2018). It had 16 items in total. Sample items included, "There is a risk for young women to contract HPV." The chronebach's alpha reliability was found to be 0.740 .

\section{Acceptability of HPV Vaccination}

The questions for the variable were taken from Grandahl et al. (2018). It had 9 items in total. Sample items included, "Do you agree with the policy of giving vaccination to every child?". The chronebach's alpha reliability was found to be 0.702 .

\section{Control Variables}

A one-way ANOVA was done to control the variable used in the study under demographical information collected. Table 1 has the results from the test. Significant relationship was found 
between beliefs and acceptability $(\mathrm{F}=2.913, \mathrm{P}=0.004)$. However, the results showed no significant differences based on religion, age, and education.

\section{Results}

Means, standard deviation, and correlation matrix are presented in Table 2. The table indicates that awareness about the HPV vaccine has a strong positive correlation with the acceptability of the HPV vaccine $(0.27, \mathrm{p}=0.056)$, which provided initial support for hypothesis 1 . Furthermore, beliefs about HPV have a strong positive correlation with the HPV vaccine's acceptability $(0.67, \mathrm{p}=0.000)$. Thus, providing initial support for hypothesis 2 .

\section{Regression Analysis}

Multiple regression analysis was done to study the effect of main as well as moderating variables. The results obtained from regression analysis have been presented in table 3. It shows that HPV vaccine awareness has no significant relationship with acceptability of HPV vaccine $(\beta=-0.139, p=0.347)$. Therefore, H1 is rejected. Furthermore, the moderating effect of belief on HPV awareness and HPV acceptance is also not significant $(\beta=0.364, p=0.455)$. The interaction effect is also not significant. Therefore, $\mathrm{H} 2$ is rejected. However, belief as an independent variable showed a strong, significant relationship with the acceptability HPV vaccine. However, this was beyond the scope of this study and was not further studied.

\section{Discussion}

The empirical analysis did not support the proposed hypothesis. There was no significant relationship found between HPV vaccine awareness and acceptability. Beliefs about HPV didn't have any moderating effect on HPV vaccination awareness and HPV vaccine acceptance. This is surprising as analysis of the literature on the subject shows results otherwise. Interestingly, when the results were run in the SPSS software, regression analysis showed that beliefs as an independent variable has a significant relationship with HPV vaccine acceptability. Perlman et al. (2014) assessed knowledge and awareness of cervical cancer in Sub-Saharan Africa. This was done by conducting a systemic peer-review study of cases where vaccinations were provided under the GAVI Alliance. The research showed positive acceptability of HPV vaccination. The level of acceptability was varied as each study had a different strategy to convey awareness about the vaccine. The strategies discussed are uncommon in Pakistan, which could explain the low acceptability in terms of awareness. However, we also believe that acceptability was not significant because most of the respondent's response to the question in section B of the questionnaire, "Do you know what HPV is?" was "No." This could mean that lack of general knowledge could be a big factor in society. Furthermore, Pakistan has a patriarchal society (Chauhan, 2014) with an overall literacy rate of less than 60\% (UNESCO UIS, 2017). This can cause an influence in decision-making. A patriarchal society might push the females not to take steps where they normally might have a say in their sexual health. In such countries, the acceptability of the vaccine is low because parents would prefer not just girls but also boys to get the vaccine as it is thought that the former get the virus from the latter (Paul et al., 2013). Another issue could be the shyness of the females in the Pakistani society towards discussion on topics of sexually 
transmitted diseases, thereby making them clueless about the infection - thereby having a complete lack of knowledge (Maan, Hussain, Iqbal and Akhtar, 2011). In some countries, these issues are overcome by communication and education. This is especially true for low and middle-income countries where social mobilizations during the introduction of new vaccines encourage parents to accept first dosage coverage (Kabakama, 2016). Mass media also plays an important role in pushing parents towards HPV vaccination by improving knowledge and promoting the vaccine, increasing its acceptability. This further increases the acceptability as well as intent to receive the vaccine.

\section{Limitations and Directions for Future Research}

While the research was carried out systematically with utmost care of avoiding research bias, it is possible that it could have affected the final decision of the respondents due to some interaction in the middle of filling out the questionnaires. Furthermore, the sample size might have been too small for obtaining the desired result; therefore, these results may not be generalizable. The patients could have filled the questionnaires randomly without paying attention to the questions. Another issue is that though the mothers interviewed had daughters; not all were between the ages of 12-13.

We must consider the fact that HPV public knowledge is extremely low for us to research its acceptability. Future studies could work on the reasons behind Pakistan's minimal work in providing public knowledge about HPV vaccination and disease. This research could shed light on the role of knowledge and acceptability.

\section{References}

Braaten, K.P. \& Laufer, M.R., 2008. Human Papillomavirus (HPV) and HPV Vaccines. SpringerReference, pp.2-10.

Brisson, M. et al., 2016. Population-level impact, herd immunity, and elimination after human papillomavirus vaccination: a systematic review and meta-analysis of predictions from transmission-dynamic models. The Lancet Public Health, 1(1).

Brotherton, J.M.L., 2019. Impact of HPV vaccination: Achievements and future challenges. Papillomavirus Research, 7, pp.138-140.

Bruni, L. et al., 2019. Human Papillomavirus and Related Diseases in the World. Summary Report. HPV Information Centre. Available at: https://www.hpvcentre.net/statistics/reports/XWX.pdf [Accessed October 2, 2019].

Capra, G. et al., 2017. Potential impact of a nonavalent HPV vaccine on HPV related low-and high-grade cervical intraepithelial lesions: A referral hospital-based study in Sicily. Human Vaccines \& Immunotherapeutics, 13(8), pp.1839-1843.

Chauhan, K., 2015. Gender inequality in the public sector in pakistan: representation and distribution of resources, New York City, NY: Palgrave Macmillan.

Chow, E.P. et al., 2017. Quadrivalent vaccine-targeted human papillomavirus genotypes in heterosexual men after the Australian female human papillomavirus vaccination programme: a retrospective observational study. The Lancet Infectious Diseases, 17(1), pp.68-77.

Clifford, G.M. et al., 2003. Comparison of HPV type distribution in high-grade cervical lesions and cervical cancer: a meta-analysis. British Journal of Cancer, 89(1), pp.101-105. 
Drolet, M. et al., 2015. Population-level impact and herd effects following human papillomavirus vaccination programmes: a systematic review and meta-analysis. The Lancet Infectious Diseases, 15(5), pp.565-580.

Grand Valley State University, 2014. Moral beliefs a barrier to HPV vaccine, researchers find. ScienceDaily. Available at: https://www.sciencedaily.com/releases/2014/07/140707141716.htm [Accessed October 13, 2019].

Grandahl, M. et al., 2018. Correction: Parents' knowledge, beliefs, and acceptance of the HPV vaccination in relation to their socio-demographics and religious beliefs: A cross-sectional study in Thailand. PLOS ONE, 13(4).

Gul, S., Murad, S. \& Javed, A., 2015. Prevalence of High-risk Human Papillomavirus in cervical dysplasia and cancer samples from twin cities in Pakistan. International Journal of Infectious Diseases, 34, pp.14-19.

Harper, D.M. \& DeMars, L.R., 2017. HPV vaccines - A review of the first decade. Gynecologic Oncology, 146(1), pp.196-204.

Kabakama, S. et al., 2016. Social mobilisation, consent, and acceptability: a review of human papillomavirus vaccination procedures in low and middle-income countries. BMC Public Health, 16(1).

Khan, S. et al., 2007. Human papillomavirus subtype 16 is common in Pakistani women with cervical carcinoma. International Journal of Infectious Diseases, 11(4), pp.313-317.

Khan, T.M. et al., 2016. Knowledge, attitudes, and perception towards human papillomavirus among university students in Pakistan. Papillomavirus Research, 2, pp.122-127.

Kim, H.W., 2015. Awareness of human papillomavirus and factors associated with intention to obtain HPV vaccination among Korean youth: quasi-experimental study. BMC International Health and Human Rights, $15(1)$.

Krawczyk, A. et al., 2015. Parents' decision-making about the human papillomavirus vaccine for their daughters: I. Quantitative results. Human Vaccines \& Immunotherapeutics, 11(2), pp.322-329.

Langsfeld, E. \& Laimins, L.A., 2016. Human Papillomaviruses: Research Priorities for the Next Decade. Trends in Cancer, 2(5), pp.234-240.

Lechuga, J., Vera-Cala, L. \& Martinez-Donate, A., 2014. HPV Vaccine Awareness, Barriers, Intentions, and Uptake in Latina Women. Journal of Immigrant and Minority Health, 18(1), pp.173-178.

Loke, A.Y. et al., 2017. The Uptake of Human Papillomavirus Vaccination and Its Associated Factors Among Adolescents: A Systematic Review. Journal of Primary Care \& Community Health, 8(4), pp.349-362.

Maan, M.A. et al., 2011. Sexually transmitted infections in Pakistan. Annals of Saudi Medicine, 31(3), pp.263269.

Paul, P. et al., 2013. Acceptability of HPV Vaccine Implementation Among Parents in India. Health Care for Women International, 35(10), pp.1148-1161.

Perlman, S. et al., 2014. Knowledge and Awareness of HPV Vaccine and Acceptability to Vaccinate in SubSaharan Africa: A Systematic Review. PLoS ONE, 9(3).

Ratanasiripong, N.T. et al., 2018. Human papillomavirus (HPV) vaccination and factors related to intention to obtain the vaccine among young college women in Thailand. Journal of Health Research, 32(2), pp.142-151.

Santhanes, D. et al., 2018. Factors influencing intention to obtain the HPV vaccine in South East Asian and Western Pacific regions: A systematic review and meta-analysis. Scientific Reports, 8(1).

Schoell, W.M., Janicek, M.F. \& Mirhashemi, R., 1999. Epidemiology and biology of cervical cancer. Seminars in Surgical Oncology, 16(3), pp.203-211.

Shelton, R.C. et al., 2011. HPV Vaccine Decision-Making and Acceptance: Does Religion Play a Role? Journal of Religion and Health, 52(4), pp.1120-1130.

UNESCO, 2017. Pakistan. UNESCO UIS. Available at: http://uis.unesco.org/en/country/pk [Accessed October 23, 2019].

World Health Organization, 2017. Human papillomavirus vaccines: WHO position paper. World Health Organization. 
Yu, Y. et al., 2016. Human Papillomavirus Infection and Vaccination: Awareness and Knowledge of HPV and Acceptability of HPV Vaccine among Mothers of Teenage Daughters in Weihai, Shandong, China. PLOS ONE, 11(1).

\section{Appendix 1}

Table 1: One-way ANOVA

Intention on HPV Vaccination

\begin{tabular}{ccc}
\hline Sources of Variation & F- Statistics & P-Value \\
\hline Education & 1.841 & 0.124 \\
\hline Age & 1.267 & 0.274 \\
\hline Religion & 1.164 & 0.334 \\
\hline Beliefs & 2.913 & 0.004 \\
\hline
\end{tabular}

Table 2: Means, Standard Deviations, Correlations, and Reliabilities

\begin{tabular}{|c|c|c|c|c|c|c|c|c|c|}
\hline & Mean & $\begin{array}{l}\text { Standard } \\
\text { Deviation }\end{array}$ & Age & Religion & Education & $\begin{array}{c}\text { General } \\
\text { Vaccination } \\
\text { Awareness }\end{array}$ & $\begin{array}{c}\text { HPV } \\
\text { Vaccination } \\
\text { Awareness }\end{array}$ & $\begin{array}{c}\text { HPV } \\
\text { Beliefs }\end{array}$ & $\begin{array}{c}\text { HPV } \\
\text { Acceptability }\end{array}$ \\
\hline Age & 30.06 & 6.20 & & & & & & & \\
\hline Religion & 1.20 & 0.57 & 0.11 & & & & & & \\
\hline Education & 2.74 & 1.21 & 0.24 & $0.284^{*}$ & & & & & \\
\hline $\begin{array}{c}\text { General } \\
\text { Vaccination } \\
\text { Awareness }\end{array}$ & 23.46 & 5.82 & 0.108 & -0.08 & -0.37 & $(0.768)$ & & & \\
\hline $\begin{array}{c}\text { HPV } \\
\text { Vaccination } \\
\text { Awareness }\end{array}$ & 25.68 & 4.43 & -0.01 & -0.14 & -0.15 & $0.45 * *$ & $(0.558)$ & & \\
\hline HPV Beliefs & 51.60 & 6.81 & 0.04 & -0.20 & 0.02 & 0.26 & $0.51 * *$ & $(0.740)$ & \\
\hline $\begin{array}{c}\text { HPV } \\
\text { Acceptability }\end{array}$ & 27.50 & 4.79 & -0.01 & -0.13 & 0.03 & 0.22 & 0.27 & $0.67 * *$ & $(0.702)$ \\
\hline
\end{tabular}

$n=50$; alpha reliabilities are given in parentheses. For age, participants wrote their ages on a blank. For Religion, 1 = Muslim, 2 = Christian, 3 = Hindu, $4=$ unknown. For education, $1=$ Middle school, $2=$ High School, 3 = Intermediates, 4 = Bachelors, 5 = Master's. 
Afifa Muhammad Afzal / The Moderating Effect of Beliefs on HPV Awareness and HPV Vaccination Acceptance Among Female Patients in Islamabad City

Table 3: Regression Analysis

\begin{tabular}{cccc}
\hline \multicolumn{3}{c}{ HPV Acceptability } \\
\hline \multicolumn{3}{c}{ Predictors } & $\Delta R^{2}$ \\
\hline HPV Vaccine Awareness & $-0.139 \mathrm{~ns}$ & $\mathrm{R}^{2}$ & $0.456^{* *}$ \\
\hline HPV Vaccine Belief & $0.491^{* *}$ & $0.456^{* *}$ & \\
\hline $\begin{array}{c}\text { (HPV Vaccine } \\
\text { Belief)*(HPV Vaccine } \\
\text { Awareness) }\end{array}$ & $0.364 \mathrm{~ns}$ & & \\
\hline
\end{tabular}

$* *$ = significant value, $\mathrm{ns}=$ not significant value 


\section{Appendix 2}

English version of the questionnaire

\section{Faculty of Management Sciences}

Tel: 0092-51-8446000-8, fax: 0092-51-8313141 email: afifarosary@gmail.com

\section{HPV Awareness Survey}

Dear Participant,

I am a student of Riphah University's Management Sciences Department. As part of my thesis, I am conducting a research on Awareness and Attitude towards HPV vaccination in Pakistan.

You can help us in our current research project by completing this questionnaire, which we think you will find quite interesting. We appreciate your participation in our study. It will take about 10-15 minutes of your precious time. We assure you that your responses will be held in strictest anonymity. Please keep in mind that the resulting data will be summarized on a general basis and not on an individual basis. If for any reason you do not want to participate in our study, please feel free to decline. If you wish to be informed of the findings of this study, the findings will be shared with you as a report discussing aggregated results only and will not disclose any raw data as this contravenes Riphah International University ethics guidelines.

Please read the instructions carefully and answer all the questions. There are no "trick" questions, so please answer each item as frankly and as honesty as possible. It is important that all the questions be answered.

We once again thank you for your assistance and cooperation in this academic pursuit.

Regards and Jazakallah,

Afifa Muhammad Afzal

MS Healthcare Management

afifarosary@gmail.com 
Please answer some questions about yourself before starting the questionnaire

\begin{tabular}{|l|l|}
\hline Your name & \\
\hline Your age & \\
\hline Country of Residence & \\
\hline Country of Birth & \\
\hline City of Residence & \\
\hline City of Birth & \\
\hline Religion & \\
\hline Occupation & \\
\hline Education & \\
\hline
\end{tabular}

Section A

Awareness on Vaccination

The following section will evaluate your awareness on general concept of vaccinations. Please tick under any one section which best suits your response.

\begin{tabular}{|l|l|l|l|l|l|l|}
\hline S.no & Question & Yes & Much & Somewhat & Little & No \\
\hline 1 & Do you know what vaccines are? & & & & & \\
\hline 2 & $\begin{array}{l}\text { Are you favorable of pediatric } \\
\text { vaccination? }\end{array}$ & & & & & \\
\hline 3 & Are you favorable of Adult Vaccination? & & & & & \\
\hline 4 & $\begin{array}{l}\text { Do you know what vaccines are available } \\
\text { today for the Pakistani population? }\end{array}$ & & & & & \\
\hline 5 & $\begin{array}{l}\text { Do you know by who and where can you } \\
\text { be vaccinated? }\end{array}$ & & & & & \\
\hline 6 & $\begin{array}{l}\text { Do you think that vaccines have any side } \\
\text { effects? }\end{array}$ & & & & & \\
\hline 7 & $\begin{array}{l}\text { Can you contract a disease even if you are } \\
\text { vaccinated? }\end{array}$ & & & & & \\
\hline 8 & $\begin{array}{l}\text { Do you think vaccination is effective even } \\
\text { after getting infected or being in contact } \\
\text { with a contagious case? }\end{array}$ & & & & & \\
\hline
\end{tabular}


Section B

\section{Awareness on HPV Vaccination}

The following section will evaluate your awareness on HPV vaccination specifically. Please tick any one section which best suits your response.

\begin{tabular}{|l|l|l|l|l|l|l|}
\hline S.no & Question & Yes & Much & Somewhat & Little & No \\
\hline 1 & Do you know what HPV is? & & & & & \\
\hline 2 & Do you think that HPV is dangerous? & & & & & \\
\hline 3 & $\begin{array}{l}\text { Do you know lesions related to HPV } \\
\text { infection? }\end{array}$ & & & & & \\
\hline 4 & $\begin{array}{l}\text { Have you heard about vaccination and } \\
\text { prevention for HPV? }\end{array}$ & & & & & \\
\hline 5 & $\begin{array}{l}\text { Do you think there is a high probability of } \\
\text { contracting HPV infection? }\end{array}$ & & & & & \\
\hline 6 & $\begin{array}{l}\text { Would you be willing to get vaccinated } \\
\text { against HPV? }\end{array}$ & & & & & \\
\hline 7 & $\begin{array}{l}\text { Do you consider it useful to consult your } \\
\text { partner regarding HPV vaccination? }\end{array}$ & & & & & \\
\hline 8 & $\begin{array}{l}\text { Do you want to receive information about } \\
\text { HPV vaccination? }\end{array}$ & & & & & \\
\hline
\end{tabular}

Matranga, D., Lumia, C., Guarneri, R., Arculeo, V. M., Noto, M., Pivetti, A., ...

Spera, A. (2019). The vaccinaTion \& Hpv Knowledge (THinK) questionnaire: a reliability and validity study on a sample of women living in Sicily (southern-Italy). PeerJ, 7, e6254. doi: $10.7717 /$ peerj. 6254 


\section{Section C}

\section{Societal Beliefs on HPV Vaccination}

This section contains questions to evaluate beliefs on HPV and HPV vaccination. Please tick any one box which best suits your beliefs.

\begin{tabular}{|c|c|c|c|c|c|c|}
\hline S.no & & $\begin{array}{l}\text { Strongly } \\
\text { disagree }\end{array}$ & Disagree & Unsure & Agree & $\begin{array}{c}\text { Strongly } \\
\text { agree }\end{array}$ \\
\hline 1 & $\begin{array}{l}\text { There is a risk for young } \\
\text { women to contract HPV }\end{array}$ & $\square$ & $\square$ & $\square$ & $\square$ & $\square$ \\
\hline 2 & $\begin{array}{l}\text { There is a risk for young } \\
\text { women to contract cervical } \\
\text { cancer }\end{array}$ & $\square$ & $\square$ & $\square$ & $\square$ & $\square$ \\
\hline 3 & $\begin{array}{l}\text { HPV infection is a serious } \\
\text { health concern }\end{array}$ & $\square$ & $\square$ & $\square$ & $\square$ & $\square$ \\
\hline 4 & $\begin{array}{l}\text { Cervical cancer is a serious } \\
\text { disease }\end{array}$ & $\square$ & $\square$ & $\square$ & $\square$ & $\square$ \\
\hline 5 & $\begin{array}{l}\text { The HPV vaccine is effective } \\
\text { in preventing condyloma }\end{array}$ & $\square$ & $\square$ & $\square$ & $\square$ & $\square$ \\
\hline 6 & $\begin{array}{l}\text { The HPV vaccine is effective } \\
\text { in preventing cervical cancer }\end{array}$ & $\square$ & $\square$ & $\square$ & $\square$ & $\square$ \\
\hline 7 & $\begin{array}{l}\text { I have trust in the HPV } \\
\text { vaccination }\end{array}$ & $\square$ & $\square$ & $\square$ & $\square$ & $\square$ \\
\hline 8 & $\begin{array}{l}\text { The HPV vaccine can cause } \\
\text { adverse effects }\end{array}$ & $\square$ & $\square$ & $\square$ & $\square$ & $\square$ \\
\hline 9 & $\begin{array}{l}\text { It is problematic that HPV } \\
\text { vaccination requires three } \\
\text { injections }\end{array}$ & $\square$ & $\square$ & $\square$ & $\square$ & $\square$ \\
\hline 10 & $\begin{array}{l}\text { The efficiency of HPV } \\
\text { vaccine is unclear }\end{array}$ & $\square$ & $\square$ & $\square$ & $\square$ & $\square$ \\
\hline 11 & The HPV vaccine is harmful & $\square$ & $\square$ & $\square$ & $\square$ & $\square$ \\
\hline 12 & $\begin{array}{l}\text { Women who have been HPV } \\
\text { vaccinated should have Pap } \\
\text { smear annually }\end{array}$ & $\square$ & $\square$ & $\square$ & $\square$ & $\square$ \\
\hline 13 & $\begin{array}{l}\text { HPV vaccination decreases c } \\
\text { pndom use }\end{array}$ & $\square$ & $\square$ & $\square$ & $\square$ & $\square$ \\
\hline 14 & $\begin{array}{l}\text { HPV vaccination causes my } \\
\text { daughter to be sexually active } \\
\text { early }\end{array}$ & $\square$ & $\square$ & $\square$ & $\square$ & $\square$ \\
\hline 15 & $\begin{array}{l}\text { HPV vaccination increases } \\
\text { number of sexual partners }\end{array}$ & $\square$ & $\square$ & $\square$ & $\square$ & $\square$ \\
\hline 16 & $\begin{array}{l}\text { HPV vaccination increases } \\
\text { awareness of sexually } \\
\text { transmitted diseases } \\
\end{array}$ & $\square$ & $\square$ & $\square$ & $\square$ & $\square$ \\
\hline
\end{tabular}


Section D

\section{General Acceptability of HPV Vaccination}

The following section will evaluate your acceptability of HPV vaccination. Please tick any one box which best suits your choice.

\begin{tabular}{|c|c|c|c|c|c|c|}
\hline S.no & & $\begin{array}{l}\text { Strongly } \\
\text { disagree }\end{array}$ & Disagree & Unsure & Agree & $\begin{array}{c}\text { Strongly } \\
\text { agree }\end{array}$ \\
\hline 1 & $\begin{array}{l}\text { Do you agree if Ministry } \\
\text { of Public Health is } \\
\text { going to offer HPV } \\
\text { vaccine for free to 9-11 } \\
\text { years old girls? }\end{array}$ & $\square$ & $\square$ & $\square$ & $\square$ & $\square$ \\
\hline 2 & $\begin{array}{l}\text { Do you agree with the } \\
\text { policy of giving } \\
\text { vaccination to every } \\
\text { child? }\end{array}$ & $\square$ & $\square$ & $\square$ & $\square$ & $\square$ \\
\hline 3 & $\begin{array}{l}\text { Do you consider } \\
\text { vaccinating yourself (for } \\
\text { mother)? }\end{array}$ & $\square$ & $\square$ & $\square$ & $\square$ & $\square$ \\
\hline 4 & $\begin{array}{l}\text { Will you accept active } \\
\text { HPV vaccination of } \\
\text { your daughter? }\end{array}$ & $\square$ & $\square$ & $\square$ & $\square$ & $\square$ \\
\hline 5 & $\begin{array}{l}\text { If your daughter is not } \\
\text { in the target group do } \\
\text { you still want to pay for } \\
\text { vaccinating her? }\end{array}$ & $\square$ & $\square$ & $\square$ & $\square$ & $\square$ \\
\hline 6 & $\begin{array}{l}\text { If the government offers } \\
\text { HPV vaccination for } \\
\text { free, I will vaccinate my } \\
\text { daughter }\end{array}$ & $\square$ & $\square$ & $\square$ & $\square$ & $\square$ \\
\hline 7 & $\begin{array}{l}\text { Now HPV vaccine costs } \\
6000-6900 \text { baht per } \\
\text { course, yet I will } \\
\text { vaccinate my daughter }\end{array}$ & $\square$ & $\square$ & $\square$ & $\square$ & $\square$ \\
\hline 8 & $\begin{array}{l}\text { I don't have enough } \\
\text { information about HPV } \\
\text { vaccine to decide } \\
\text { whether to give it to my } \\
\text { daughter }\end{array}$ & $\square$ & $\square$ & $\square$ & $\square$ & $\square$ \\
\hline 9 & $\begin{array}{l}\text { HPV vaccine is so new } \\
\text { that I want to wait a } \\
\text { while before deciding to } \\
\text { get it. }\end{array}$ & $\square$ & $\square$ & $\square$ & $\square$ & $\square$ \\
\hline
\end{tabular}

Thank you for your time! 


\section{Appendix 3}

Translated version of the questionnaire

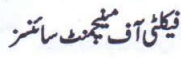

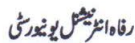

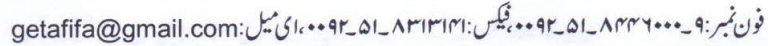

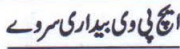

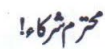

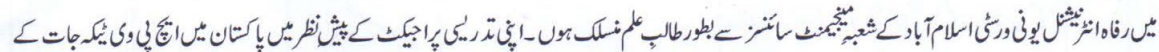

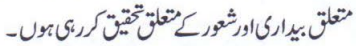

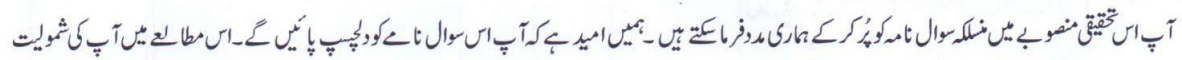

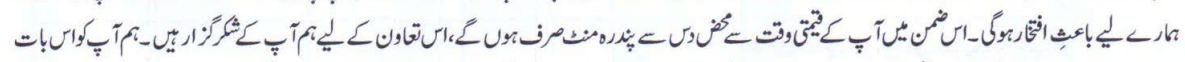

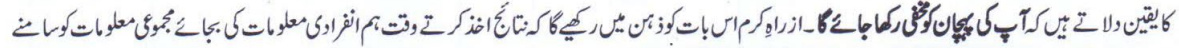

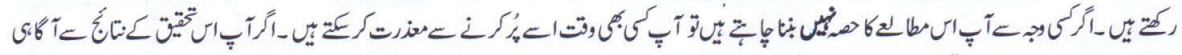

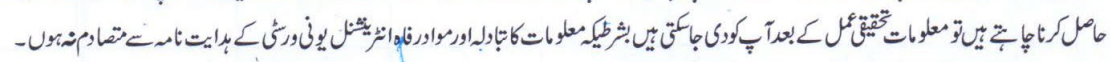

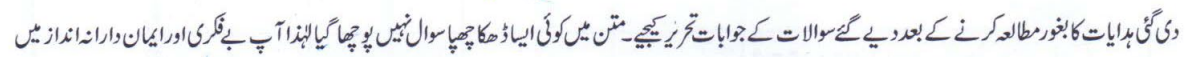

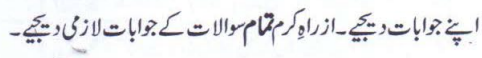

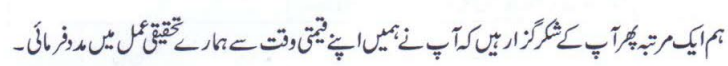

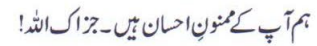

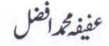

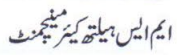
getafifa@gmail.com

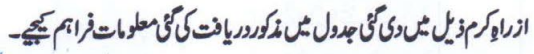

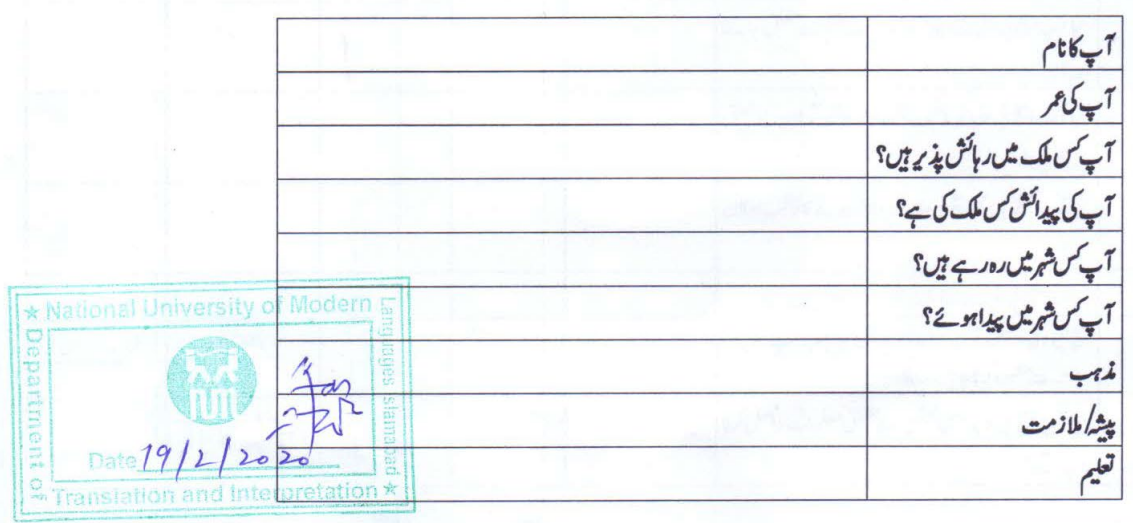




\section{$-10 \div$

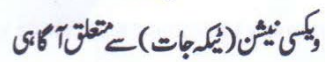

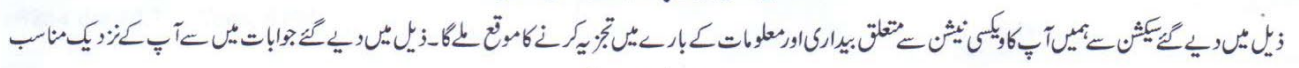

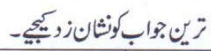

\begin{tabular}{|c|c|c|c|c|c|c|}
\hline לخئي & تحوراسا & كئمسيك & زيإه & ulu. & بوال & مثبرثر \\
\hline & & & & & 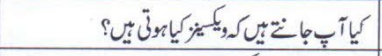 & -1 \\
\hline & & & & & 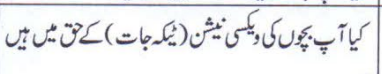 & $-r$ \\
\hline & & & & & 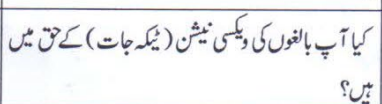 & $-r$ \\
\hline & & & & & 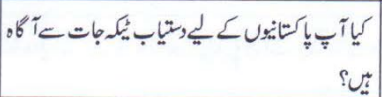 & $-r$ \\
\hline & & & & & 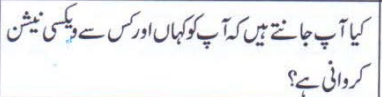 & $-ه$ \\
\hline & . & & & & 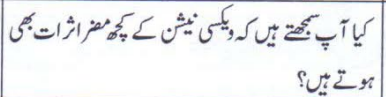 & -4 \\
\hline & & & & & 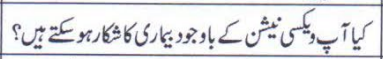 & -4 \\
\hline & $\AA$ & & & $\therefore$ & 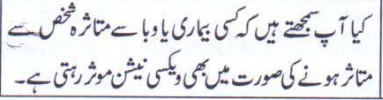 & $-\wedge$ \\
\hline
\end{tabular}

بك

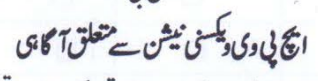

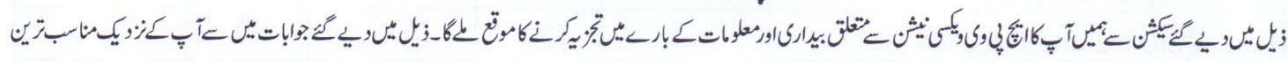

\begin{tabular}{|c|c|c|c|c|c|c|}
\hline \multicolumn{7}{|c|}{ 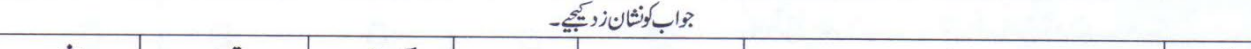 } \\
\hline & & & & & S & -1 \\
\hline & & & & ? & 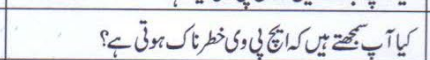 & $-r$ \\
\hline & & & & & 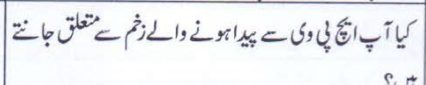 & . $-r$ \\
\hline & & & & & 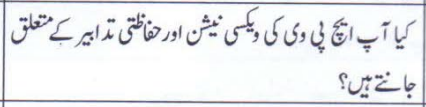 & $-r$ \\
\hline & & & & & 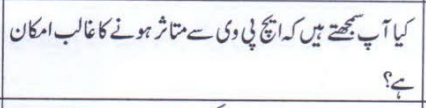 & $-ه$ \\
\hline & & & & & 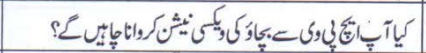 & -4 \\
\hline National Uni & ersity of Mllod & o & & & 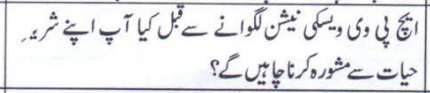 & -4 \\
\hline & (119) & & & & 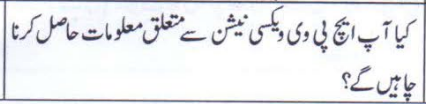 & $-\wedge$ \\
\hline
\end{tabular}


Matranga,D., Lumia, C., Guarneri, R.,Arculeo,V.M., Noto, M., Pivetti,A.,...Spera, A. (2019). The vaccination \& Hpv Knowledge (Think) Questionnaire: a reliability study on a sample of women living in Sicily ( southern-Italy). PeerJ, 7 , e6254.doi: $10.7717 /$ peej. 6254

$$
\begin{aligned}
& 50^{4}
\end{aligned}
$$

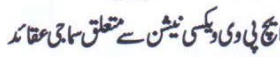

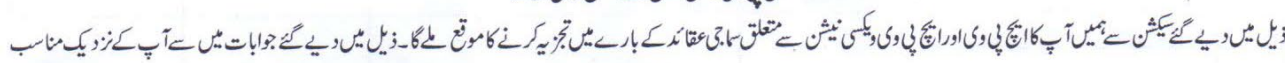

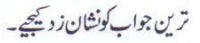

\begin{tabular}{|c|c|c|c|c|c|c|}
\hline كاتنت & تثنית & 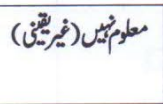 & تخنئ & 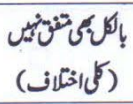 & 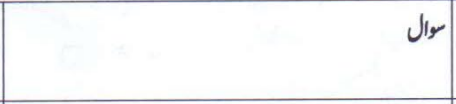 & تجرثار \\
\hline$\square$ & 口 & 口 & $\square$ & $\square$ & 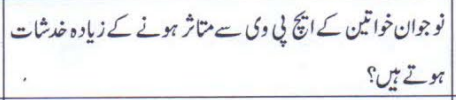 & -1 \\
\hline$\square$ & $\square$ & $\square$ & $i^{\square}$ & $\square \quad-$ & 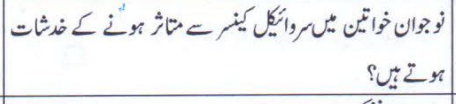 & $-r$ \\
\hline 口 & $\square$ & $\square$ & . & $\square$ & 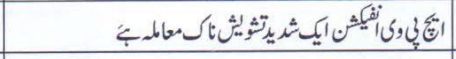 & $-r$ \\
\hline$\square$ & $\square$ & $\square$ & $\square$ & 口 & 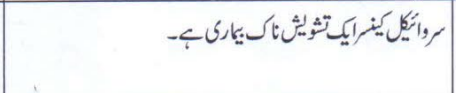 & $-r$ \\
\hline$\square$ & $\square$ & $\square$ & $\square$ & $\square$ & 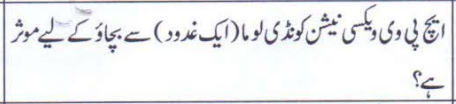 & هـ \\
\hline$\square$ & $\square$ & $\square$ & $\square$ & $\square$ & 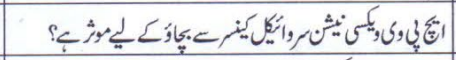 & -4 \\
\hline$\square$ & $\square$ & $\square$ & $\square$ & $\square$ & | & $-\angle$ \\
\hline$\square$ & $\square$ & $\square$ & $\square$ & $\square$ & 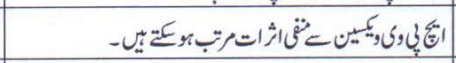 & $-\Lambda$ \\
\hline$\square$ & 口 & $\square$ & $\square$ & 口 & $\mid$ & -9 \\
\hline 口 & $\square$ & $\square$ & $\square$ & $\square$ & 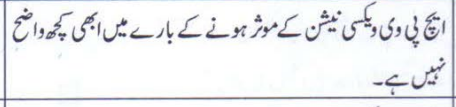 & $-1 *$ \\
\hline$\square$ & $\square$ & $\square$ & $\square$ & $\square$ & 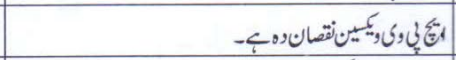 & -11 \\
\hline$\square$ & 口 & 口 & 口 & $\square$ & | & - ir \\
\hline$\square$ & $\square$ & $\square$ & $\square$ & $\square$ & 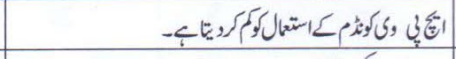 & - Ir \\
\hline$\square$ & 口 & 口 & 口 & 口 & 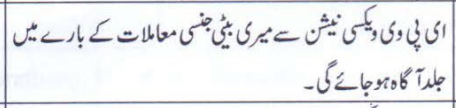 & $-! r$ \\
\hline$\square$ & $\square$ & & $\square$ & $\square$ & 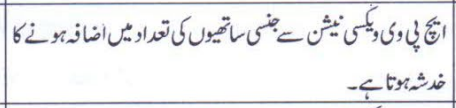 & -10 \\
\hline 口 & $\square$ & 2 & 口 & 口 & 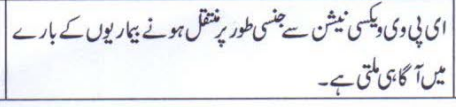 & -14 \\
\hline
\end{tabular}




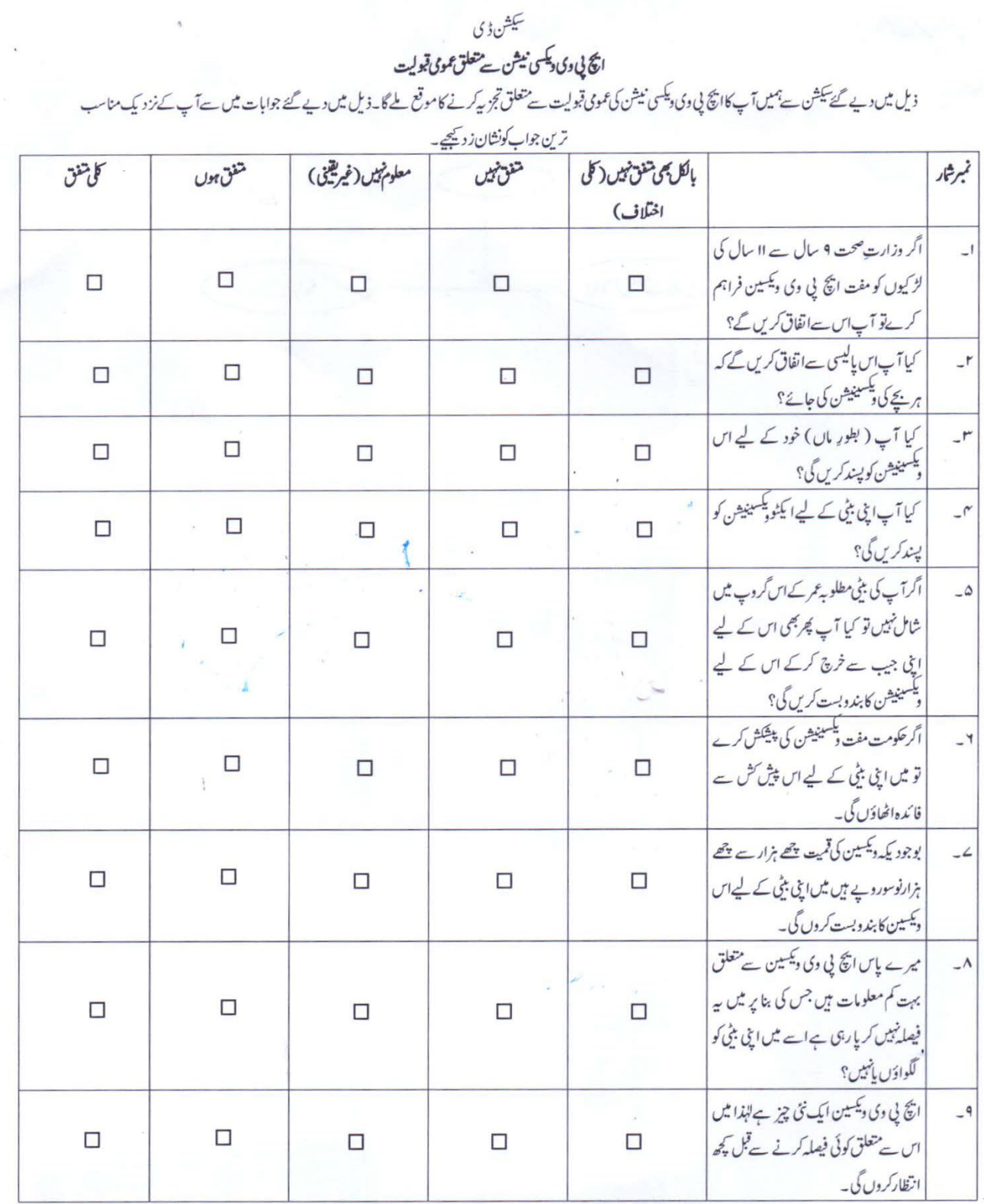

Grandahl, M., Paek, S.C., Grisurapong, S., Sherer, P., Tyden, T. , \& Lundberg, P. (2018). Correctio: Parents'

Knowledge, Beliefs, and acceptance of the HPV vaccination in relation to their socio-demographics and religious beliefs: A cross-sectional study in Thailand. PLOS ONE , 13(4), e01965437.doi:10.1371/journal.pone.0196437

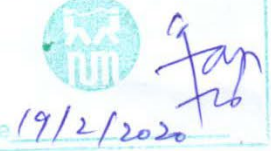




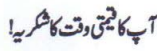

S6)
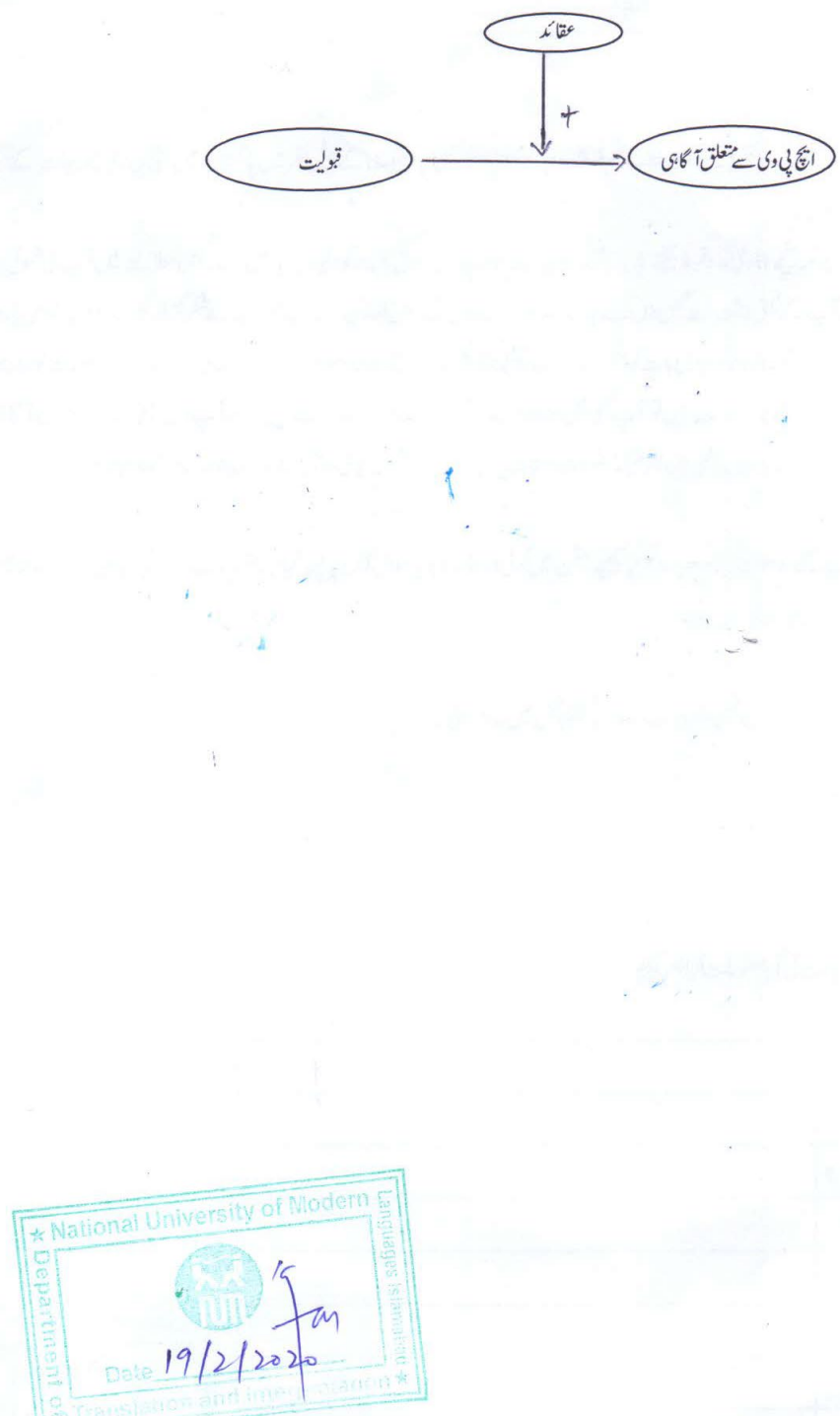